\title{
Öğretmenlerine Göre Din Kültürü ve Ahlak Bilgisi Dersinin Din Öğretimi Modelleri Çerçevesinde Konumlandırılması
}

\author{
Doç. Dr. Ibrahim AŞLAMACl*
}

Atıf / @-- Aşlamacı, İ. (2018). Öğretmenlerine Göre Din Kültürü ve Ahlak Bilgisi Dersinin Din Öğretimi Modelleri Çerçevesinde Konumlandırılması, Çukurova Üniversitesi İlahiyat Fakültesi Dergisi, 18 (2), 718-744.

Öz- Bu araştırmada Din Kültürü ve Ahlak Bilgisi (DKAB) öğretmenlerinin DKAB derslerini din öğretimi modelleri çerçevesinde nasıl konumlandırdıklarının tespit edilmesi ve bazı değişkenler açısından incelenmesi amaçlanmıştır. Araştırma betimsel tarama ve karşılaştırmalı ilişkisel tarama modellerinde tasarlanmıştır. Araştırmanın örneklemini, Malatya ili merkez ilçelerinde 2017-2018 öğretim yılında görev yapan 187 Din Kültürü ve Ahlak Bilgisi öğretmeni oluşturmuştur. Araştırmada veri toplama aracı olarak araştırmacı tarafından geliştirilen 16 maddelik "Öğretmen DKAB Algı Ölçeği" kullanılmıştır. Araştırma sonucunda Din Kültürü ve Ahlak Bilgisi öğretmenlerinin büyük çoğunluğunun DKAB derslerini dini öğrenme yaklaşımına uygun bir ders olarak konumlandırdıkları tespit edilmiştir.

Anahtar sözcükler- Din kültürü ve ahlak bilgisi, din dersi öğretmeni, din öğretimi modelleri, dini öğrenme, din hakkında öğrenme, dinden öğrenme.

\section{$\S \S \S$}

\section{Giriş}

İnsanların inandıkları dini bilme ve sonraki nesillere aktarma intiyacı sonucu ortaya çıkan din eğitimi ile ilgili tarihten günümüze değişen yaşam koşulları ile birlikte farklı uygulamalar ve anlayışlar ortaya çıkmıştır. Dinin devletle sıkı bir ilişki içinde olduğu dönemlerde, devletin pek çok kademesinde olduğu gibi eğitimde de dini kurumlar belirleyici olmuş, eğitim bu kurumların etkisinde dini nitelikli olarak sunulmuştur. Bu dönemin ardından modern dönemde sekülerleşmeyle birlikte eğitimin de dini niteliği ortadan kalkmış; din, eğitimi verilecek bir konu haline dönüşmüş ve devlet okullarında diğer seküler

\footnotetext{
*İnönü Üniversitesi İlahiyat Fakültesi İlköğretim Din Kültürü ve Ahlak Bilgisi Eğitimi Bölümü e-posta: ibrahim.aslamaci@inonu.edu.tr ORCID: 0000-0002-9030-5216
} 
derslerden bir ders olabilmek için meşruiyet mücadelesi sürdürmek durumunda kalmıştır. Bu süreçte insanların din eğitimi intiyacının nasıl karşılanacağı, okul programlarında dinin yer alıp almayacağı, öğretime konu olması durumunda hangi modellerin kullanılacağı toplumdan topluma, kültürden kültüre farklılık göstermiştir. Her ülkenin dini haritası, din-devlet ilişkisi, din algılamaları, dinin fert ve toplum üzerindeki etki düzeyi gibi değişkenler bu konuda belirleyici olmaktadır. ${ }^{1} \mathrm{Bu}$ nedenle din eğitimi politika ve pedagojik yaklaşımlarının oluşmasını, sözü edilen değişkenlerden bağımsız düşünmek mümkün gözükmemektedir.

Bununla birlikte özellikle 2000'li yıllardan itibaren, öncesinde büyük ölçüde ulusal değişkenlere bağlı olarak şekillenen, din eğitimi politika ve pedagoji anlayışlarına uluslararası boyut önemli bir faktör olarak eklenmiştir. ${ }^{2}$ Daha önce okullarda din dersleriyle hiç ilgilenmeyen UNESCO, Avrupa Konseyi ve Avrupa Güvenlik ve İşbirliği Teşkilatı (AGIT) gibi uluslararası kuruluşlar, bu süreçte güvenlikle ilişkilendirdikleri din eğitiminin okullarda nasıl bir yaklaşımla yer alabileceğine dair genel ilkeler belirleyen çeşitli çalışmalar yürütmüşlerdir. ${ }^{3}$ Bu çalışmalarda din eğitimi ve öğretimi insan hakları ve inanç özgürlüğü çerçevesinde bir hak tarzında değerlendirilmeye çalışılmaktadır. Bu süreçte bir anlamda okullarda din öğretimi konusunda nelerin kabul edilebilir, nelerin kabul edilemez olduğuna dair, uluslararası seviyede daha önce hiç bulunmayan gelenekler oluşturulmaya başlanmıştır.

Din Kültürü ve Ahlak Bilgisi (DKAB) dersi ülkemizde anayasal olarak 1982 yılından itibaren ilk ve ortaöğretim kurumlarında zorunlu olarak okutulan dersler arasında yer almaktadır. Ancak bu derslerin hukuki statüsü ve içeriği toplumun farklı kesimleri tarafından sürekli tartışılan bir mesele halini almıştır. Özellikle 2000'li yıllardan itibaren bu konudaki tartışmaların hukuk alanına da taşındığı görülmektedir. Bu derslerin zorunluluğu üzerine yürütülen tartışmalara, çocuklarını bu derslerden muaf tutmak isteyen velilerin başvuruları sonucunda 2007 ve 2014 yıllarında Avrupa İnsan Hakları Mahkemesi'nin (AïHM) vermiş olduğu kararlar da eklenmiştir. Gerek 2007

\footnotetext{
${ }^{1}$ Robert Jackson, Rethinking Religious Education and Plurality (London and Newyork: Routledge Falmer, 2004), 4.

${ }^{2}$ Recep Kaymakcan, Gençlerin Dine Bakışı: Karşılaştırmalı Türkiye ve Avrupa Araştırması (İstanbul: Dem Yayınları, 2007), 58.

${ }^{3}$ Söz konusu kuruluşların raporları hakkında Bkz. COUNCiL of Europe, Religious Diversitiy and Intercultural Education: A Reference Book For Schools; OSCE, Toledo Guiding Principles on Teaching About Religions and Beliefs in Public Schools; Robert Jackson, "Devlet Okullarında Din Eğitimi ve Değerler Eğitimine Yorumcu Yaklaşımın Katkısı", Değerler ve Eğitimi (İstanbul, 26-28Kasım 2004), ed. Recep Kaymakcan vd. (İstanbul: Dem Yayınları, 2007), s.467-488.
} 
yılındaki "Hasan ve Eylem Zengin-Türkiye" davasında gerekse de 2014 yılındaki "Mansur Yalçın ve Diğerleri-Türkiye" davasında AïHM'nin kararlarından; devlet okullarında zorunlu din derslerinin varlığını, tek başına İnsan Hakları Sözleşmesi'ne aykırı görmediği, ancak ölçüt olarak, söz konusu eğitimin "tarafsız, eleştirel ve çoğulcu" bir yaklaşımla verilmesini ve herhangi bir sistematik telkinde/fikir aşılamasında bulunulmamasını ileri sürdüğü anlaşılmaktadır. Her iki kararında da AlHM, bu kriterleri karşılama açısından DKAB derslerinin öğretim programlarını yetersiz bulmuştur. Bu gelişmeler karşısında Milli Eğitim Bakanlığı dersin hukuki statüsünü değiştirmekten ziyade, dersin müfredatında 2010 ve 2018 yıllarında değişikliğe giderek, içeriğinin daha kapsayıcı hale getirilmesine ilişkin bir takım düzenlemeler yapmıştır. Hazırlanan bu programlar Türkiye'nin aynı zamanda okullardaki din öğretiminde benimsediği yaklaşım/model konusunda geldiği noktayı göstermesi bakımından da önem taşımaktadır.

Literatürde az sayıda da olsa öğretmenlerinin DKAB öğretim programlarına ilişkin görüşlerini inceleyen çeşitli çalışmalar bulunmaktadır. Bu çalışmalardan Işıkdoğan ve Korukcu Diyarbakır ve Çorum il merkezlerinde görev yapan ilköğretim DKAB öğretmenlerinin program hakkındaki görüşlerini incelemiş, programın öğretmenler tarafından benimsenmekle birlikte programı anlaşılması ve uygulanması noktasında onların çeşitli sıkıntılar yaşadıkları sonucuna ulaşmışlardır. ${ }^{4}$ Kaymakcan tarafından 2008 yılında Türkiye geneli 25 farklı ilden toplam 774 DKAB öğretmenine uygulanan ve onların yenilenen DKAB programları hakkındaki çeşitli görüşlerinin tespitini amaçlayan çalışmada, programın öğretmenlerin çoğu tarafından tam olarak incelenmediği ve hazırlanırken temele alınan yaklaşımları yeterince bilmedikleri tespit edilmiştir. ${ }^{5}$ Yürük tarafından Adana il merkezinde görev yapan DKAB öğretmenlerine yönelik yapılan çalışmada ise öğretmenlerin DKAB programlarının eğitimsel ve dinbilimsel yaklaşımlarına ilişkin görüşleri ele alınmıştır. Çalışmada genel olarak öğretmenlerin programın eğitim ve dinbilimsel anlayışlarının programa yansıması ile ilgili olumlu düşünce içerisinde oldukları tespit edilmiştir. ${ }^{6}$ Zengin tarafından İstanbul'da görev yapan

\footnotetext{
${ }^{4}$ Davut Işıkdoğan ve Adem Korukcu, "Illköğretim Din Kültürü ve Ahlak Bilgisi Dersi Öğretim Programı ve Öğretmenlerin Programa Yönelik Görüşleri”, Dini Araştırmalar 11/32, (Eylül-Aralık 2008): 237-258.

${ }^{5}$ Recep Kaymakcan, Öğretmenlerine Göre Din Kültürü ve Ahlak Bilgisi Dersleri Yeni Eğilimler: Çoğulculuk ve Yapılandırmacılık (İstanbul: Dem Yayınları, 2009).

6 Tuğrul Yürük, "Öğretmenlerin İlköğretim Din Kültürü ve Ahlak Bilgisi Dersi Öğretim Programının Din

Anlayışına Yönelik Düşünceleri (Adana Örneği), Dini Araştırmalar, 18/46, (Ocak-Haziran 2015):
} 
20 DKAB öğretmeni ile yapılan nitel araştırmada öğretmenlerin genellikle programların eğitimsel yaklaşımına ilişkin görüşler ifade ettikleri, buna karşılık dinbilimsel yaklaşıma ilişkin görüş belirtmedikleri tespit edilmiştir. ${ }^{7}$ Kızılabdullah ve Yürük tarafından yapılan çalışmada ise din öğretimi modelleri çerçevesinde Türkiye'deki din eğitimi üzerine genel bir değerlendirme yapılmış ve incelenen DKAB dersi için 2006 yılında hazırlanan programdan hareketle bu dersin dinden öğrenme modeline daha yakın olduğu, din hakkında öğrenme yaklaşımının da bazı prensiplerini yansıttığı sonucuna ulaşılmıştır. ${ }^{8}$

İlgili literatür incelendiğinde çeşitli açılardan öğretmenlerin DKAB programlarıyla ilgili görüşlerini tespit etmeye yönelik az sayıda da olsa çalışmalar yürütüldüğü ve programla ilgili öğretmen görüşlerine yer verildiği görülmektedir. Ancak öğretmenlerin din öğretimi modelleri çerçevesinde DKAB dersini nasıl konumlandırdıklarına ilişkin yapılmış herhangi bir çalışma tespit edilememiştir. Esasında DKAB dersleri üzerindeki yürütülen tartışmalar daha çok dolaylı olarak öğretmenlerinin öğretim sürecindeki tutum ve davranışlarına ilişkindir. Nitekim bu derslerin öğretim programlarında teorik olarak ne yazdığından ziyade pratikte DKAB öğretmenlerin bu programlardan ne anladıkları ve programı nasıl uyguladıkları daha fazla önem taşımaktadır. $\mathrm{Bu}$ nedenle öğretmenlerinin yürüttükleri DKAB derslerine ilişkin nasıl bir algıya sahip olduklarının tespiti, bu derslerin programlarında çerçevesi çizilen amaçları doğrultusunda yürütülmesi açısından önem taşımaktadır. Bu gereklilikten hareketle araştırmanın temel problemi DKAB öğretmenlerinin Din Kültürü ve Ahlak Bilgisi derslerini din öğretimi modelleri çerçevesinde nasıl konumlandırdıklarının betimlenmesi oluşturmaktadır.

\section{Din Öğretimi Modelleri}

Günümüz okullarındaki din öğretiminin değişen ve çeşitlenen ihtiyaçlar doğrultusunda yeniden ele alınması ve sorgulanmasına verilmiş farklı cevaplar olarak değerlendirilebilecek din öğretimi modellerine ilişkin farklı sınıflamalar söz konusudur. İlgili literatüre bakıldığında okullarda yer alan din derslerinde belirli bir dinin benimsetilmesinin esas alınıp alınmaması bakımından, temelde iki farklı yaklaşımın olduğu görülmektedir. Din eğitimi alanında bu durumu

148- 170.; Tuğrul Yürük, “Öğretmenlere Göre İlköğretim DKAB Dersi Öğretim Programının Eğitim Anlayışı (Adana Örneği), Dini Araştırmalar, 17/45, (Temmuz-Aralık 2014): 171-207.

${ }^{7}$ Mahmut Zengin, "Yeni İlköğretim DKAB Öğretim Programının Uygulamadaki Etkililiğinin Değerlendirilmesi. Sakarya Üniversitesi Illahiyat Fakültesi Dergisi, 12/22, 2010:121-160.

${ }^{8}$ Yıldız Kızılabdullah, Tuğrul Yürük, "Din Eğitimi Modelleri Çerçevesinde Türkiye'deki Din Eğitimi Üzerine Genel Bir Değerlendirme”, Dini Araştırmalar, 11/32, (Eylül-Aralık 2008): 107-129. 
nitelemek için "confessional" ve "non-confessional" kavramları kullanılmaktadır. $\mathrm{Bu}$ kavramlardan confessional Türkçeye mezhebe dayalı / savunmacı / doktriner şeklinde, non-confessional ise mezhepler üstü / savunmacı olmayan / doktriner olmayan diye tercüme edilmektedir. Ülkelerin din eğitimi konusunda uyguladığı modeller farklııı arz etse de, ya da dinlerarası, kültürlerarası, fenomenolojik, yorumlayıcı, sorgulayıcı, doktriner, inanç temelli, teokratik vb. din öğretimi şeklinde değişik adlandırılsa da, temelde bu iki modelden birisine yakın durduğu söylenilebilir. Bu araştırmada ise son dönemde literatürde öne çıkan Michael Grimmitt tarafından geliştirilen ve sınıflandırımasında John Hull'un katkı sağladığı "dini öğrenme", "din hakkında öğrenme" ve "dinden öğrenme" şeklindeki sınıflandırma esas alınmıştır. ${ }^{9}$ Bu modelleri ve temel özelliklerini şu şekilde betimlemek mümkündür:

\subsection{Dinî Öğrenme Modeli:}

Geleneksel ya da savunmacı olarak da adlandırılan dini öğrenme modeli, eğitim programı içerisinde yalnızca tek bir dini geleneğin, kendi dinamiklerinden hareketle öğretildiği modeldir. Bu yaklaşımın temel özelliği, belli bir dinî inancı açık veya örtük olarak benimsetmeye çalışmasıdır. Bu modelde öğretimin temel amacı öğrencilere o dini sevdirmek, benimsettirmek ve onları o dinin inanırı yapmaktır. Öğrencilerin kendi dinlerinin gerçek olduğuna inanmaları sağlanarak dinle bağlarının güçlendirilmesi hedeflenir. Böylece dinî öğrenme yaklaşımının amacı, dinin istediği şekilde bireyi dindar bir insan olarak yetiştirmek şeklinde özetlenebilir. ${ }^{10}$ Böylelikle bu yaklaşımda dersin amacı ile ilgili dinin amacı paralellik arz etmektedir.

Bu yaklaşımda öğretmenin öğrettiği dine inanması ve dinî geleneklere bağlı olması beklenir. Dersin adı da daha ziyade Katolik din dersi, Protestan din dersi, İslam din dersi gibi ilgili dinin veya mezhebin adı ile anılmaktadır. Bu modelle hazırlanan din eğitimi programlarında ilgili din/mezhep, ağırlıklı olarak yer alırken; bilgi düzeyinde de olsa diğer din veya mezheplerin de öğretilmesi mümkün olabilmektedir. Ancak benimsetilmeye çalışılan dinin dışında farklı

\footnotetext{
${ }^{9}$ Michael Grimmit, "Contemporary Pedagogies of Religious Education: What are they?", Pedagogies of Religious Education, (UK, McCrimmons, 2000): 24-52; John M. Hull, "Demokratik Çoğulcu Toplumlarda Din Eğitimi Üzerine Genel Değerlendirme”, Din Öğretiminde Yeni Yöntem Arayışları, Uluslar arası Sempozyum Bildiri ve Tartışmalar (İstanbul, 28-30 Mart 2001), (Ankara, MEB Yayınları, 2003), 44.

${ }^{10}$ Hull, “Demokratik Çogulcu Toplumlarda Din Eğitimi Üzerine Genel Değerlendirme”, 44.
} 
dinlerin öğretildiği durumda, farklı dinlere merkeze alınan dinin bakış açısına göre yer verilmektedir. ${ }^{11}$

Uzun yıllar okullarda din eğitiminde uygulanan bu model günümüzde halen birçok ülkede etkili olmaya devam etmektedir. Bu yaklaşım, birden fazla dinin olduğu ve din eğitiminin devlet okullarının dışında özel veya vakıf okullarına bırakıldığı ülkeler ile toplumda tek bir din veya mezhep mensuplarının çoğunluk olarak yaşadığı, söz konusu din ya da mezhebin devlet tarafından tanındığı bölgelerde uygulama alanı bulmaktadır. ${ }^{12}$ Örneğin Almanya'da din öğretimi, Katolik ve Protestan din dersi gibi ilgili dinin veya mezhebin adı anılarak ve o mezhebin ilkeleri çerçevesinde bu modele uygun olarak yapılmaktadır. ${ }^{13}$ Yine devletin Vatikan ile yaptığı anlaşma gereği devlet okullarında yalnızca Katolik mezhebine yer verildiği, diğer Hıristiyan mezheplerinin ve farklı dinlerin dışlandığı İtalya'da, bu model uygulanmaktadır. ${ }^{14}$ Amerika Birleşik Devletleri gibi çokkültürlü ve çok dinli ülkelerde de, özel (paralı) ya da kilise okullarında bu modele rastlanmaktadır. ${ }^{15}$

Dini öğrenme yaklaşımına yöneltilen en önemli eleştiri, bu yaklaşımın günümüzün seküler, çoğulcu ve çok inançlı toplumlarına hitap edemeyeceğine ilişkindir. Bu düşünceye göre çokkültürlü bir yapının hâkim olduğu ve herhangi bir dini inancı benimsemeyen öğrencilerin sayılarının giderek arttığı okullarda dini öğrenme yaklaşımının uygulanmasının, din eğitiminin toplum içerisindeki huzursuzlukların kaynağı olmasına neden olabileceğidir. Yine öğrencilerin kendi intiyaçlarından hareketle hazırlanmadığı için bu yaklaşımla hazırlanan programları sıkıcı buldukları, bu şekildeki bir yaklaşımın din ve inanç özgürlüğüne aykırılık teşkil edebileceği, laiklik ilkesini benimseyen ülkelerde devletin tarafsızlık ilkesiyle çelişeceği gibi çeşitli eleştiriler yöneltilmektedir. ${ }^{16}$ Ayrıca bu yaklaşımın öğretilen dine özgürlük sağladığı, fakat öğrencilerin özgürlüğünü artırmadığı, onların bilişsel ufkunu genişletmediği ve başka dinleri

\footnotetext{
${ }^{11}$ Kaymakcan, Gençlerin Dine Bakışı: Karşılaştırmalı Türkiye ve Avrupa Araştırması, 62.; Kızılabdullah ve Yürük, "Din Eğitimi Modelleri Çerçevesinde Türkiye'deki Din Eğitimi Üzerine Genel Bir Değerlendirme", 109-111.

${ }^{12}$ Cemal Tosun, Din Eğitimi Bilimine Giriş (Ankara, Pegem A Yayıncılık, 2001), 134.

${ }^{13}$ Bkz. Recai Doğan, "Avrupa Birliği Sürecinde Dini Kurumlar ve Din Eğitimi: Almanya Modeli”, Avrupa Birliği Sürecinde Dini Kurumlar ve Din Eğitimi Uluslararası Sempozyum, (İstanbul 17-19 Kasım 2006), (İstanbul, Dem Yayınları, 2007): 255-299.

${ }^{14}$ Bkz. Alessandro Ferrari, "Avrupa Birliği Sürecinde Dini Kurumlar ve Din Eğitimi: İtalya Modeli”, Avrupa Birliği Sürecinde Dini Kurumlar ve Din Eğitimi Uluslararası Sempozyum, (İstanbul 17-19 Kasım 2006), (İstanbul, Dem Yayınları, 2007): 461-480.

${ }^{15}$ Bkz. Yıldız Kızılabdullah, "Dini Öğrenme Modelinin” Çok Dinli /Çokkültürlü Toplumlardaki

Tezahürleri. Pegem Eğitim ve Öğretim Dergisi, 5(5), 723.

${ }^{16}$ Eleştiriler için bkz. Kızılabdullah ve Yürük, "Din Eğitimi Modelleri Çerçevesinde Türkiye'deki Din Eğitimi Üzerine Genel Bir Değerlendirme”, 111-113.
} 
kendi inanç sistemlerine göre değerlendirdiği için önyargılar oluşturmalarına yol açarak başka din mensuplarının dünyalarını anlamayı engellediği ifade edilmektedir. ${ }^{17}$

\subsection{Din Hakkında Öğrenme Modeli}

Din hakkında öğrenme yaklaşımı geleneksel dini öğrenme yaklaşımının günümüz seküler ve çoğulcu toplumunda yetersizliğine karşı bir tepki olarak ortaya çıkmıştır. Bu yaklaşımın temel özelliği öğrencilere herhangi bir dinin içeriğinin benimsetilmesinden ziyade, din olgusunun dinlerin içeriklerinden örneklerle objektif biçimde sunulmasıdır. Dinlerin öğretiminde inanç ve değerlerin meşruluğu veya doğruluğu hakkında tartışmalara girilmez. Din hakkında araştırmayı, sorgulamayı içerir. Öğrenci din araştırmalarında inançlar, öğretiler ve ibadet şekilleri, dinî kaynaklar ve hayat şekilleri ve inananların dinî tecrübeleri hakkında öğrenir. Dinin, içinden yani kendi dinamiklerinden öğretilmesi yerine betimleyici ve tarihsel perspektiften hareketle dışarıdan öğretilmesi esas alınır. Bu bakımdan bu yaklaşım bir üst isimlendirme olarak algılandığında dinler tarihi, karşılaştırmalı din çalışmaları, din fenomenolojisi veya dinler etnolojisi gibi alanlarla ilgilidir ve karşılaştırmalı din eğitimi olarak da adlandırılmaktadır. Dolayısıyla bu modelde bilimsel dini çalışmalar anlayışı hâkimdir. ${ }^{18}$

$\mathrm{Bu}$ model bireylere belli bir dini benimsetme amacı gütmez. Aksine bireye dinler hakkında bilgi vermeyi amaçlar. Din, bu modelde betimsel, objektif, tarihsel ve eleştirel bir tarzda sunulur. Tarafsız bir din eğitimi anlayışı kabul edilir. Bu modelde tek bir dine üstünlük tanımanın aksine, herhangi bir dinin esaslarını içermeyen bir din eğitimi verilmeye çalışılır. ${ }^{19}$ Din hakkında öğrenme modelinde öğretmenin inançlı olması şartı aranmaz. Öğretmen, öğrencilerin belli bir dine bağlı olmanın ve dinî yaşamın ne anlama geldiğini anlamalarına katkı sunar. Öğretim sürecinde dinî fenomenler, yani dinlerin dinî anlayış ve yaşayış tarzları dengeli bir şekilde objektif/nesnel tavır içerisinde öğrencilere sunulmaya çalışılır. ${ }^{20}$

\footnotetext{
${ }^{17}$ Muhittin Okumuşlar, "Çokkültürlü Toplumlarda Din Hakkında ve Dinden Öğrenme Modeli," Marife, 7/2, (Güz 2007), 254.

${ }^{18}$ Hull, "Demokratik Çogulcu Toplumlarda Din Eğitimi Üzerine Genel Değerlendirme", s. 44.; Robert Jackson, "Avrupa'da Kurumlar ve Din Öğretimi-Öğreniminin Kamusal alandaki Genel Eğitime Katkısı", Avrupa Birliği Sürecinde Dini Kurumlar ve Din Eğitimi Uluslararası Sempozyum, (İstanbul 17-19 Kasım 2006), (İstanbul, Dem Yayınları, 2007), 123.

${ }^{19}$ Kızılabdullah ve Yürük, "Din Eğitimi Modelleri Çerçevesinde Türkiye'deki Din Eğitimi Üzerine Genel Bir Değerlendirme”, 114.

${ }^{20}$ Seyfullah Bazarkulov, Değer Öğretimi ve Dinden Öğrenme, (Doktora Tezi Ankara Üniversitesi, 2008), 107.
} 
Din hakkında öğrenme yaklaşımı, fenomenolojik yöntemlerle dinlerin içeriklerine odaklanma eğiliminde olması ve dinî hoşgörü açısından olumlu katkı sağlamasına rağmen eğitimsel açıdan öğrencilerin ihtiyaç ve sorunlarından hareket etmediği, onların ahlaki ve manevi değer arayışlarına sınırlı katkısından dolayı eleştirilmiştir. Çünkü bu yaklaşımda bireysel deneyimleri geliştirmek yerine dinlerin içeriğinin objektif olarak sunulması esastır. ${ }^{21}$

\subsection{Dinden Öğrenme Modeli}

Din hakkında öğrenme yaklaşımının eksikliklerinden hareketle Grimmitt tarafından geliştirilmiş olan dinden öğrenme modeli, eğitimsel değeri oldukça fazla olan ve öğrencinin ihtiyaçlarını merkeze alan bir yaklaşımdır. Bu tür din öğretiminin esas amacı, öğrencilere insani davranış kazandırıp onların ahlaki ve ruhsal gelişimlerine katkı sağlamak ya da dini konular hakkında kendi bakış açılarını geliştirmelerine katkı sağlamaktır. Bu yaklaşımda öğrencilerin farklı dinleri, her dinin kendi bakış açısı ve kaynaklarına göre öğrenerek, kendi bireysel deneyimlerini keşfetmeleri hedeflemektedir. ${ }^{22}$ Bu model öğrencilerin ahlâkî ve manevî gelişimine katkıda bulunan, başlıca hedefi öğrencileri insancıllaştırmak olan bir din eğitimidir. Bu yaklaşımda temel soru; çocuklar ve gençler ne ölçüde, hangi yollarla din eğitiminden fayda sağlayabileceklerdir? sorusudur. ${ }^{23}$

Dini öğrenme dinin kendi anlayışının, din hakkında öğrenme ise bilimsel din çalışmasının kontrolü altında iken, dinden öğrenme eğitimsel çalışmaların içinde bir disiplin olmuştur. Dini öğrenme ve din hakkında öğrenme yaklaşımlarında din, ya çocuklara benimsetilecek bir inanç objesi ya da eleştirel çalışmaya uygun bir konu olarak öğretilmektedir. Dinden öğrenme yaklaşımında ise din çocuklar ve öğretmenlere odaklanır ve onlar için öğretilir. Dinin kendisi insancıllaşma sürecine yardımcı olmaktadır. Bu yaklaşımda ana hedef çocuğun eğitimine katkıda bulunmaktır. Bu sebeple bu yaklaşım "eğitimsel din eğitimi" olarak da adlandırımaktadır. ${ }^{24}$

\section{Araştırmanın Amacı}

\footnotetext{
${ }^{21}$ Hull, "Demokratik Çoğulcu Toplumlarda Din Eğitimi Üzerine Genel Değerlendirme”, 45.

22 Okumuşlar, "Çokkültürlü Toplumlarda Din Hakkında ve Dinden Öğrenme Modeli”, 256.

${ }^{23}$ Hull, "Demokratik Çoğulcu Toplumlarda Din Eğitimi Üzerine Genel Değerlendirme”, 45.

${ }^{24}$ Hull, "Demokratik Çoğulcu Toplumlarda Din Eğitimi Üzerine Genel Değerlendirme", 45.
} 
Bu araştırmanın temel amacı DKAB öğretmenlerinin Din Kültürü ve Ahlak Bilgisi derslerini din öğretimi modelleri çerçevesinde nasıl konumlandırdıklarının incelenmesidir. Ayrıca öğretmenlerin DKAB derslerine ilişkin algılarını bazı değişkenler açısından (cinsiyet, öğrenim durumu, yaş ve mezun olunan program) incelenmesi amaçlanmıştır. Bu amaç doğrultusunda araştırmada aşağıdaki sorulara cevap aranmıştır:

1- DKAB öğretmenleri yürüttükleri DKAB derslerini din öğretimi modelleri çerçevesinde (dini öğrenme, din hakkında öğrenme, dinden öğrenme) nasıl konumlandırmaktadır?

2- Öğretmenlerin $D K A B$ derslerine ilişkin algılarında cinsiyet, öğrenim durumu, yaş ve mezun olunan program değişkenleri açısından anlamlı bir farklılık ortaya çıkmakta mıdır?

\section{Hipotezler}

Araştırmanın hipotezleri şu şekilde kurgulanmıştır:

1- Öğretmenler yürüttükleri DKAB derslerini din öğretimi modelleri çerçevesinde dini öğrenme modeline uygun konumlandırmaktadır.

2- Cinsiyet açısından öğretmenlerin DKAB derslerini konumlandırmalarında anlamlı bir farklılık yoktur.

3- Lisansüstü öğrenime sahip DKAB öğretmenleri lisans mezunu öğretmenlere göre DKAB derslerini din hakkında ve dinden öğrenme modellerine daha fazla oranda uygun bulmaktadır.

4- Genç DKAB öğretmenleri ileri yaştaki meslektaşlarına göre DKAB derslerini din hakkında ve dinden öğrenme modellerine daha fazla oranda uygun bulmaktadır.

5- DKAB öğretmenliği bölümü mezunu öğretmenler, İlahiyat lisans ve İLITAM programlarından mezun olan öğretmenlere göre DKAB derslerini din hakkında ve dinden öğrenme modellerine daha fazla oranda uygun bulmaktadır.

\section{Yöntem}

\subsection{Araştırmanın Modeli}


Bunun için araştırma, nicel araştırma desenlerinden betimsel tarama modeli ile tasarlanmıştır. Betimsel tarama modeli, geçmişte ya da halen var olan bir durumu var olduğu şekliyle betimlemeyi amaçlayan araştırma yaklaşımıdır. Ayrıca araştırma DKAB öğretmenlerinin görüşlerinin bazı değişkenler açısından karşılaştırmayı amaçladığından karşılaştırmalı ilişkisel tarama modeline dayandırılmıştır. ${ }^{25}$

\subsection{Evren ve Örneklem}

Araştırmanın ulaşılabilir evreni 2017-2018 öğretim yılı bahar dönemi itibariyle Malatya ili merkez ilçelerindeki eğitim kurumlarında görev yapan 411 Din Kültürü ve Ahlak Bilgisi öğretmenidir. Örneklem ise söz konusu dönemin sonunda yapılan seminer çalışmasına katılan ve anketi doldurmayı kabul eden 187 DKAB öğretmeninden oluşmuştur. Öğretmenlerin demografik özelliklerine ilişkin bulgular aşağıdaki şekildedir:

Tablo 1: Araştırmaya Katılan DKAB Öğretmenlerinin Demografik Özellikleri

\begin{tabular}{|l|l|c|c|}
\hline \multirow{4}{*}{ Cinsiyet } & & $\boldsymbol{f}$ & $\%$ \\
\hline \multirow{4}{*}{ Yaş } & Erkek & 78 & 41,7 \\
\cline { 2 - 4 } & Kadın & 109 & 58,3 \\
\hline \multirow{4}{*}{$\begin{array}{l}\text { Öğrenim Durumu } \\
\text { Prozun Olunan Lisans }\end{array}$} & $22-25$ & 30 & 16,0 \\
\cline { 2 - 4 } & $26-30$ & 39 & 20,9 \\
\cline { 2 - 4 } & $31-40$ & 77 & 41,2 \\
\cline { 2 - 4 } & $41-50$ & 29 & 15,5 \\
\cline { 2 - 4 } & 51 ve üzeri & 12 & 6,4 \\
\hline & Lisans & 37 & 79,7 \\
\cline { 2 - 4 } & Lisansüstü & 93 & 49,7 \\
\cline { 2 - 4 } & İlahiyat lisans & 16 & 8,6 \\
\cline { 2 - 4 } & İlahiyat önlisans+ İLITAM & 77 & 41,2 \\
\cline { 2 - 4 } & DKAB & & \\
\hline
\end{tabular}

Tablo 1'de görüldüğü gibi araştırmaya katılan DKAB öğretmenlerinin \% 41,7'si erkek, \% 58,3'ü kadındır. Öğretmenlerin yaklaşık yarısının (77 kişi, \%41,2) yaşı 31-40 arasındadır. Geri kalan \%20,9'u 26-30 yaş, \%16'sı 22-25 yaş, \%15,5'i 41-50 yaş ve \%6,4'ü 51 ve üzeri yaş aralığına sahiptir. Örneklemi oluşturan öğretmenlerin \%79,7'si lisans, \%19,8'i ise lisansüstü derecesine sahiptir. Öğretmenlerin yaklaşık yarısı $(\% 49,7)$ İlahiyat lisans, \%41,2'si din

\footnotetext{
${ }^{25}$ Niyazi Karasar, Bilimsel Araştırma Yöntemi (Ankara: Nobel Yayınları, 1999), 78-81.
} 
Kültürü ve Ahlak Bilgisi öğretmenliği ve geri kalan \%8,6'sı İlahiyat önlisans + İlitam programından mezun olmuştur.

\subsection{Veri Toplama Araçları}

Araştırmada veri toplama aracı olarak demografik sorulara ilişkin kişisel bilgi formu ve araştırmacı tarafından geliştirilen 16 maddelik "Öğretmen DKAB Algı Ölçeği” kullanılmıştır. Kişisel bilgi formunda öğretmenlerin cinsiyet, yaş öğrenim durumları gibi olgusal durumlarına yönelik sorular yer almıştır.

“DKAB Öğretmen Algı Ölçeği”: Araştırmada öğretmenlerinin DKAB derslerini din öğretimi modelleri çerçevesinde nasıl konumlandırdıklarını tespit etmek için araştırmacı tarafından "Öğretmen DKAB Algı Ölçeği” geliştirilmiştir. Ölçek geliştirme sürecinde öncelikle din öğretimi modellerine ilişkin literatür taraması yapılmış ve John Hull ve Michael Grimmitt tarafından geliştirilen dini öğrenme, din hakkında öğrenme ve dinden öğrenme şeklindeki sınıflandırmadaki din öğretimi modellerinden her birini betimleyen temel bilgiler maddeler halinde yazılarak madde havuzu oluşturulmuştur. Din eğitimi bilimi alanında görev yapan üç uzmandan görüş alınarak oluşturulan taslak madde formuna gerekli düzeltmeler yapılmış ve bir ölçek formu hazırlanmıştır. Ölçeğin yapı geçerliliği ve güvenirlik çalışması asıl uygulama sonucunda elde edilen veriler üzerinde gerçekleştirilmiştir.

Ölçeğin yapı geçerliliğinin sağlanabilmesi için faktör analizi (Principal Component Analysis) yapılmıştır. Bu analiz öncesinde verilerin faktör analizine uygun olup olmadığını belirlemek amacıyla yapılan Kaiser Mayer Olkin (KMO) ve Barlett testi sonucunda KMO değeri ,792; Barlett testi değeri ise .00 anlamlı $(p<.01)$ bulunmuştur. Söz konusu değerler ölçeğin faktör analizi için uyumlu olduğunu göstermiştir. ${ }^{26}$

Ölçeğe yapılan geçerlik analizi sonucunda herhangi bir boyut altında yeterli yük değerlerine ulaşmayan maddeler ölçekten çıkartılmıştır. Yapılan işlem sonucunda üç boyutta toplanan toplam 16 maddeli "Öğretmen DKAB Algı Ölçeği” elde edilmiştir. Tüm maddeler tutarlı biçimde önceden tasarlanan ilgili faktörlerin altına yüklenmiştir. Ölçeğin boyutları, temel alınan sınıflandırmaya uygun olarak dini öğrenme, din hakkında öğrenme ve dinden öğrenme şeklinde adlandırılmıştır. Üç boyutun açıkladığı toplam varyans oranı $\% 50,88$ olarak tespit edilmiştir. Maddelerin faktör yükleri ,507 ile ,792 arasında değişmiştir.

${ }^{26}$ Ezel Tavşancıl, Tutumların Ölçülmesi ve SPSS ile Veri Analizi (Ankara:Nobel Yayıncılık, 2014), 46-51. 
Ölçeğin güvenilirlik düzeyinin belirlenmesi amacıyla hesaplanan Croanbach Alpha iç tutarlılık katsayısı sonucunda ölçeğin bütünü için alfa değeri ,745 olarak bulunmuştur. Bu değerler ölçeğin geçerlik ve güvenirlik değerlerini sağladığını göstermektedir. Ölçeğin boyutları, maddelerin faktör yükleri, toplam korelasyonları, toplam varyansı açıklama oranları ve güvenirlik katsayısı tablo 2'de sunulmuştur.

Tablo 2: Öğretmen DKAB Algı Ölçeği Maddeleri, Faktör Yükleri ve Toplam Korelasyonları

\begin{tabular}{|c|c|c|c|c|}
\hline & 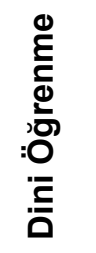 & 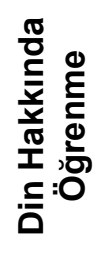 & 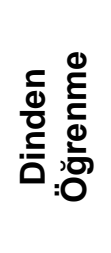 & $\begin{array}{l}\text { Madde } \\
\text { Toplam } \\
\text { r'si }\end{array}$ \\
\hline $\begin{array}{l}\text { 4- DKAB dersleri öğrencilerin daha } \\
\text { iyi Müslüman olmalarına } \\
\text { çalışmalıdır. }\end{array}$ & ,792 & & & 625, \\
\hline $\begin{array}{l}\text { 1- DKAB derslerinde öğrencilere } \\
\text { İslam dini benimsetilmelidir. }\end{array}$ & ,768 & & & 598 \\
\hline $\begin{array}{l}\text { 7- DKAB dersleri öğrencilere } \\
\text { gerçek dinin İslam olduğunu } \\
\text { öğretmelidir. }\end{array}$ & ,722 & & & ,527, \\
\hline $\begin{array}{l}\text { 14- DKAB dersi öğretmenlerinin } \\
\text { inancı kuvvetli, Müslüman birisi } \\
\text { olması gerekir. }\end{array}$ & 626 & & & 494, \\
\hline $\begin{array}{l}\text { 10- DKAB dersleri öğrencilerin } \\
\text { İslam'la olan bağlarını } \\
\text { güçlendirmelidir. }\end{array}$ & ,577 & & & 451, \\
\hline $\begin{array}{l}\text { 8- DKAB derslerinde İslam } \\
\text { benimsetici tarzda değil, betimleyici } \\
\text { tarzda öğretilmelidir. }\end{array}$ & & ,698 & & 565, \\
\hline $\begin{array}{l}\text { 11- DKAB dersleri öğrencilere } \\
\text { sadece dinin hayatı } \\
\text { anlamlandırmadaki rolünü fark } \\
\text { ettirmelidir. }\end{array}$ & & 689 & & 403, \\
\hline $\begin{array}{l}\text { 15- DKAB derslerinde } \\
\text { öğretmenlerin dinler arasında } \\
\text { tarafsızlık sergilemesi gerekir. }\end{array}$ & & ,675 & & 620, \\
\hline $\begin{array}{l}\text { 5- DKAB dersleri öğrencilerin } \\
\text { sadece dinler hakkında bilimsel } \\
\text { bilgi kazanmalarını hedeflemelidir. }\end{array}$ & & ,666 & & 529, \\
\hline
\end{tabular}




\begin{tabular}{|c|c|c|c|c|}
\hline $\begin{array}{l}\text { 2- DKAB derslerinde İslam da dahil } \\
\text { tüm dinler tarafsız bir biçimde } \\
\text { öğretilmelidir. }\end{array}$ & & ,564 & & ,450 \\
\hline $\begin{array}{l}\text { 13- DKAB derslerinde farklı dinler } \\
\text { sadece tanıtıcı olarak, olumlu } \\
\text { olumsuz herhangi bir niteleme } \\
\text { yapılmadan öğretilmelidir. }\end{array}$ & & ,507 & & ,382 \\
\hline $\begin{array}{l}\text { 6- DKAB dersleri dini gayelerden } \\
\text { ziyade eğitimsel amaçlarla } \\
\text { şekillenmelidir. }\end{array}$ & & & ,773 &, 606 \\
\hline $\begin{array}{l}\text { 3- DKAB dersleri öğrencilerin dini } \\
\text { konularda kendi bakış açılarını } \\
\text { geliştirmelerine yardımcı olmalıdır. }\end{array}$ & & & ,687 & ,499 \\
\hline $\begin{array}{l}\text { 20- DKAB dersleri öğrencilerin dini } \\
\text { anlayabilme güçlerini, yani din } \\
\text { hakkında okur-yazarlık becerilerini } \\
\text { geliştirmeyi amaçlamalıdır. }\end{array}$ & & & 672 & ,441 \\
\hline $\begin{array}{l}\text { 16- DKAB dersleri sorgulayıcı, } \\
\text { eleştirici, bilgiyi üreten vb. } \\
\text { özelliklere sahip öğrenciler } \\
\text { yetiştirmeyi hedeflemelidir. }\end{array}$ & & & 670 & ,470 \\
\hline $\begin{array}{l}\text { 18- DKAB dersleri öğrencilerin } \\
\text { özgür seçimleriyle kendi değer } \\
\text { sistemlerini oluşturmalarına katkı } \\
\text { sunmalıdır. }\end{array}$ & & & ,623 & ,483 \\
\hline Açıklanan Varyans & 18,899 & 17,964 & 14,020 & \\
\hline Açıklanan Toplam Varyans & \multicolumn{4}{|c|}{50,883} \\
\hline Cronbach Alpha Katsayısı & ,761 & ,763 & ,659 & \\
\hline Cronbach Alpha Katsayısı Genel & \multicolumn{4}{|c|}{,745 } \\
\hline
\end{tabular}

\subsection{Verilerin Toplanması ve Analizi}

Araştırmada veriler, 2017-2018 öğretim yılı bahar yarıyılı sonundaki seminer döneminde Malatya İl Milli Eğitim Müdürlüğü ve İnönü Üniversitesi İlahiyat Fakültesi işbirliği ile gerçekleştirilen hizmet içi program sırasında Malatya ili merkez ilçelerindeki ilk ve ortaöğretim kurumlarında görev yapan DKAB öğretmenlerine yüz yüze bizzat araştırmacı tarafından uygulanan anket ile toplanmıştır. Öğretmenlere öncelikle araştırma hakkında bilgi verilmiş, kimliklerini yazmalarına gerek olmadığı ifade edilerek, cevaplarının sadece bilimsel amaçla kullanılacağı bildirilmiştir. 
Araştırmada elde edilen veriler SPSS 22.0 paket programına aktarılmıştır. Verilerin analizinde betimsel istatistiklere yer verilmiştir. Verilerin normal dağılıp dağılmadığının tespiti için Kolmogorov Smirnov normallik testi yapılmıştır. Test sonucunda basıklık ve çarpıklık değerlerinin $-1,5$ ile +1,5 arasında olması nedeniyle verilerin normal dağıldığı kabul edilmiştir. ${ }^{27} \mathrm{Bu}$ nedenle DKAB dersinin modeline ilişkin öğretmen algılarının çeşitli değişkenlere göre anlamlı düzeyde farklılaşıp farklılaşmadığını tespit etmek için ikili gruplar için t-testi, ikiden fazla gruplar için ise tek yönlü varyans analizi (ANOVA) uygulanmıştır. Grupların aldıkları puanların farklılaştığı sonuçlarda farklılaşan grupları bulmak amacıyla, grupların ortalama puanları arasında Post-Hoc çoklu karşılaştırma testlerinden LSD analizi kullanılmıştır.

Araştırmada gerçekleştirilen analizlerde anlamlılık düzeyi .05 olarak kabul edilmiştir. Öğretmenlerin ölçeklerin her bir maddesi için verdikleri cevapların puanlanmasında olumlu maddelerde "tamamen katılıorum" seçeneğine 5, "katılıyorum" seçeneğine 4, "kararsızım" seçeneğine 3, "katılmıyorum" seçeneğine 2 ve "hiç katılmıyorum" seçeneğine 1 puan verilmiş, olumsuz maddelerde ise puanlama olumlu maddelerin tersi yönde yapılmıştır.

\section{Bulgular}

5.1. Öğretmenlerin DKAB Derslerini Din Öğretimi Modelleri Çerçevesindeki Konumlandırmalarına İlişkin Betimsel Bulgular

Öğretmenlerin DKAB derslerini din öğretimi modelleri çerçevesindeki konumlandırmalarına ilişkin betimsel bulgular tablo 3 'te sunulmuştur.

Tablo 3: Öğretmenlerin DKAB Derslerini Din Öğretimi Modelleri Çerçevesindeki Konumlandırmalarına İlişkin Betimsel Bulgular

\begin{tabular}{|l|c|c|c|}
\hline & $\mathrm{N}$ & $\mathrm{X}$ & Ss \\
\hline Dini Öğrenme & 187 & 4,54 &, 578 \\
\hline Din Hakkında Öğrenme & 187 & 2,84 &, 997 \\
\hline Dinden Öğrenme & 187 & 3,93 &, 629 \\
\hline
\end{tabular}

Tablo 3'te öğretmenlerin DKAB derslerini din öğretimi modelleri çerçevesinde nasıl konumlandırdıklarına ilişkin betimsel bulgular yer almıştır.

\footnotetext{
${ }^{27}$ Barbara. G. Tabachnick ve Linda S. Fidell, Using Multivariate Statistics (sixth ed.), (Boston: Pearson, 2013), 86-89.
} 
Tabloda görüldüğü gibi DKAB öğretmenlerinin büyük bir çoğunluğu yürüttükleri DKAB derslerini dini öğrenme yaklaşımına uygun bir ders olarak konumlandırmaktadır $(X=4,54)$. Yine öğretmenlerin önemli bir kısmı bu dersleri dinden öğrenme yaklaşımına uygun bir ders olarak algılarken $(X=3,93)$, öğretmenlerin en az katılım gösterdikleri yaklaşımın din hakkında öğrenme yaklaşımı olduğu görülmektedir $(X=2,84)$. Bu durumda öğretmenler yürüttükleri DKAB derslerini din öğretimi modelleri çerçevesinde dini öğrenme modeline uygun konumlandıracakları şeklindeki araştırmanın birinci hipotezi doğrulanmıştır.

\subsection{Bağımsız Değişkenlere İlişkin Bulgular}

Tablo 4: Cinsiyet Değişkenine Göre Öğretmenlerin DKAB Derslerini Din Öğretimi Modelleri Çerçevesinde Konumlandırmalarına İlişkin t Testi Analizi

\begin{tabular}{|c|c|c|c|c|c|c|}
\hline & Cinsiyet & $\mathrm{N}$ & $\mathrm{X}$ & Ss. & $\mathrm{t}$ & $p$ \\
\hline \multirow{2}{*}{ Dini Öğrenme } & Erkek & 78 & 4,62 & ,532 & \multirow{2}{*}{1,714} & \multirow{2}{*}{,088 } \\
\hline & Kadın & 109 & 4,47 & ,604 & & \\
\hline \multirow{2}{*}{$\begin{array}{l}\text { Din Hakkında } \\
\text { Öğrenme }\end{array}$} & Erkek & 78 & 2,66 & 1,005 & \multirow{2}{*}{$-2,069$} & \multirow{2}{*}{,040 } \\
\hline & Kadın & 109 & 2,96 & ,977 & & \\
\hline \multirow{2}{*}{$\begin{array}{l}\text { Dinden } \\
\text { Öğrenme }\end{array}$} & Erkek & 78 & 3,85 & ,692 & \multirow{2}{*}{$-1,332$} & \multirow{2}{*}{,184 } \\
\hline & Kadın & 109 & 3,98 & ,576 & & \\
\hline
\end{tabular}

Tablo 4 incelendiğinde, öğretmenlerinin DKAB derslerini din öğretimi modelleri çerçevesinde konumlandırmalarına ilişkin puan ortalamalarında cinsiyet değişkeninin dini öğrenme ve dinden öğrenme yaklaşımlarında anlamlı bir farklılık oluşturmadığı, buna karşılık din hakkında öğrenme yaklaşımında istatistiksel olarak anlamlı bir farklılığa yol açtığı görülmektedir ( $t=-2,069$, $\mathrm{p}<.05)$. Yapılan $\mathrm{t}$ testi analizi sonucunda, DKAB derslerini din hakkında öğrenme yaklaşımına uygun bir ders olarak konumlandıran kadın DKAB öğretmenlerinin $(X=2,96)$ erkeklere göre $(X=2,66)$ anlamlı şekilde daha fazla olduğu anlaşılmaktadır. Buna göre kadın DKAB öğretmenleri, erkek meslektaşlarına göre DKAB derslerini daha fazla oranda din hakkında öğrenme yaklaşımına uygun bir ders olarak algılamaktadır. Bu verilere göre cinsiyet değişkeni açısından öğretmenlerin DKAB derslerini konumlandırmalarında anlamlı bir farklılığın olmayacağı şeklindeki araştırmanın ikinci hipotezi dini öğrenme ve dinden öğrenme modelleri için doğrulanmış, ancak din hakkında öğrenme modeli için doğrulanmamıştır. 
Tablo 5: Öğrenim Durumu Değişkenine Göre Öğretmenlerin DKAB Derslerini Din Öğretimi Modelleri Çerçevesinde Konumlandırmalarına İlişkin t Testi Analizi

\begin{tabular}{|c|c|c|c|c|c|c|}
\hline & $\begin{array}{l}\text { Öğrenim } \\
\text { Durumu }\end{array}$ & N & $x$ & Ss. & $t$ & $\mathrm{p}$ \\
\hline \multirow{2}{*}{$\begin{array}{l}\text { Dini } \\
\text { Öğrenme }\end{array}$} & Lisans & 149 & 4,57 & ,541 & \multirow{2}{*}{1,690} & \multirow{2}{*}{,093 } \\
\hline & Lisansüstü & 37 & 4,39 & ,699 & & \\
\hline \multirow{2}{*}{$\begin{array}{l}\text { Din Hakkında } \\
\text { Öğrenme }\end{array}$} & Lisans & 149 & 2,80 & ,984 & \multirow{2}{*}{,- 808} & \multirow{2}{*}{,420 } \\
\hline & Lisansüstü & 37 & 2,94 & 1,003 & & \\
\hline \multirow{2}{*}{$\begin{array}{l}\text { Dinden } \\
\text { Öğrenme }\end{array}$} & Lisans & 149 & 3,88 & ,641 & \multirow{2}{*}{$-1,998$} & \multirow{2}{*}{,047 } \\
\hline & Lisansüstü & 37 & 4,10 & ,526 & & \\
\hline
\end{tabular}

Tablo 5 incelendiğinde, öğretmenlerinin DKAB derslerini din öğretimi modelleri çerçevesinde konumlandırmalarına ilişkin puan ortalamalarında öğrenim durumu değişkeninin dini öğrenme ve din hakkında öğrenme yaklaşımlarında anlamlı bir farklıı̆̆a yol açmadığı, sadece dinden öğrenme yaklaşımında istatistiksel olarak anlamlı bir farklılık oluşturduğu görülmektedir $(t=-1,998, p<.05)$. Yapılan $t$ testi analizi sonucunda, DKAB derslerini dini öğrenme yaklaşımına uygun bir ders olarak konumlandıran lisansüstü öğrenime sahip DKAB öğretmenlerinin $(X=4,10)$ lisans derecesine sahip öğretmenlere göre $(X=3,88)$ anlamlı şekilde daha fazla olduğu anlaşıımaktadır. Buna göre lisansüstü mezunu DKAB öğretmenleri, lisans derecesine sahip meslektaşlarına göre DKAB derslerini daha fazla oranda dinden öğrenme yaklaşımına uygun bir ders olarak algılamaktadır. Bu durumda lisansüstü öğrenime sahip DKAB öğretmenleri lisans mezunu öğretmenlere göre DKAB derslerini din hakkında ve dinden öğrenme modellerine daha fazla oranda uygun bulacakları şeklindeki araştırmanın üçüncü hipotezi dinden öğrenme modeli için doğrulanmış, ancak din hakkında öğrenme modeli için doğrulanmamıştır.

Tablo 6: Yaş Değişkenine Göre Öğretmenlerin DKAB Derslerini Din Öğretimi Modelleri Çerçevesinde Konumlandırmalarına İlişkin ANOVA Testi Analizi

\begin{tabular}{|l|l|r|l|l|l|l|l|}
\hline & Yaş & $\mathbf{N}$ & $\mathbf{X}$ & Ss & $\mathbf{F}$ & $\mathbf{P}$ & LSD \\
\hline \multirow{3}{*}{$\begin{array}{l}\text { Dini } \\
\text { Öğrenme }\end{array}$} & 1) $22-25$ & 30 & 4,36 &, 665 & & & $1<5 ;$ \\
\cline { 2 - 6 } & 2) $26-30$ & 39 & 4,47 &, 589 & \multirow{4}{*}{2,570} & $\mathbf{0}, 040$ & $2<5 ;$ \\
\cline { 2 - 5 } & 3) $31-40$ & 77 & 4,60 &, 538 & & & $3<5 ;$ \\
\cline { 2 - 5 } & 4) $41-50$ & 29 & 4,48 &, 606 & & & $4<5$ \\
\hline
\end{tabular}




\begin{tabular}{|c|c|c|c|c|c|c|}
\hline & $\begin{array}{l}\text { 5) } 51 \mathrm{ve} \\
\text { izeri }\end{array}$ & 12 & 4,93 & ,230 & & \\
\hline \multirow{5}{*}{$\begin{array}{l}\text { Din } \\
\text { Hakkında } \\
\text { Öğrenme }\end{array}$} & 1) $22-25$ & 30 & 3,02 & ,922 & \multirow{5}{*}{,672 } & \multirow{5}{*}{,613 } \\
\hline & 2) $26-30$ & 39 & 2,74 & ,964 & & \\
\hline & 3) $31-40$ & 77 & 2,83 & ,972 & & \\
\hline & 4) $41-50$ & 29 & 2,92 & 1,037 & & \\
\hline & $\begin{array}{l}\text { 5) } 51 \text { ve } \\
\text { izeri }\end{array}$ & 12 & 2,54 & 1,363 & & \\
\hline \multirow{5}{*}{$\begin{array}{l}\text { Dinden } \\
\text { Öğrenme }\end{array}$} & 1) $22-25$ & 30 & 3,98 & ,587 & \multirow{5}{*}{,626 } & \multirow{5}{*}{,644 } \\
\hline & 2) $26-30$ & 39 & 3,93 & ,639 & & \\
\hline & 3) $31-40$ & 77 & 3,93 &, 569 & & \\
\hline & 4) $41-50$ & 29 & 3,97 & ,499 & & \\
\hline & \begin{tabular}{|l}
$5) 51 \mathrm{ve}$ \\
izeri
\end{tabular} & 12 & 3,66 & 1,185 & & \\
\hline
\end{tabular}

Tablo 6'da yaş değişkenine göre öğretmenlerin DKAB derslerini din öğretimi modelleri çerçevesinde konumlandırmalarına ilişkin tek yönlü varyans analizi (ANOVA) sonuçları yer almıştır. Yapılan analiz sonucunda öğretmenlerin yaş aralığı değişkeninin din hakkında öğrenme ve dinden öğrenme yaklaşımlarında anlamlı bir farklılığa yol açmadığı, sadece dini öğrenme yaklaşımında istatistiksel olarak anlamlı bir farklılık oluşturduğu görülmektedir $(F=2,570, p<.05)$. Farklıığın hangi hangi yaş aralıklarındaki öğretmenlerin puan ortalamaları arasında olduğunu tespit etmek için post-hoc testlerinden LCD analizi yapılmıştır. Post-hoc LSD analizi sonucuna göre 51 ve üzeri yaşa sahip DKAB öğretmenleri diğer yaş aralıklarındaki öğretmenlere göre $D K A B$ derslerini daha fazla oranda dini öğrenme yaklaşımına uygun bir ders olarak algılamaktadır. Bu durumda genç DKAB öğretmenleri ileri yaştaki meslektaşlarına göre DKAB derslerini din hakkında ve dinden öğrenme modellerine daha fazla oranda uygun bulacakları şeklindeki araştırmanın dördüncü hipotezi doğrulanmamıştır.

Tablo 7: Mezun Olunan Program Değişkenine Göre Öğretmenlerin DKAB Derslerini Din Öğretimi Modelleri Çerçevesinde Konumlandırmalarına İlişkin ANOVA Testi Analizi

\begin{tabular}{|l|l|c|c|c|c|c|c|}
\hline & Program & $\mathbf{N}$ & $\mathbf{X}$ & Ss & $\mathbf{F}$ & $\mathbf{p}$ & $\begin{array}{c}\text { LS } \\
\mathbf{D}\end{array}$ \\
\hline Dini & İlahiyat lisans & 9 & 4,5 &, 57 & 1,5 &, 22 & \\
Öğrenme & & 3 & 5 & 0 & 08 & 4 & \\
\hline
\end{tabular}




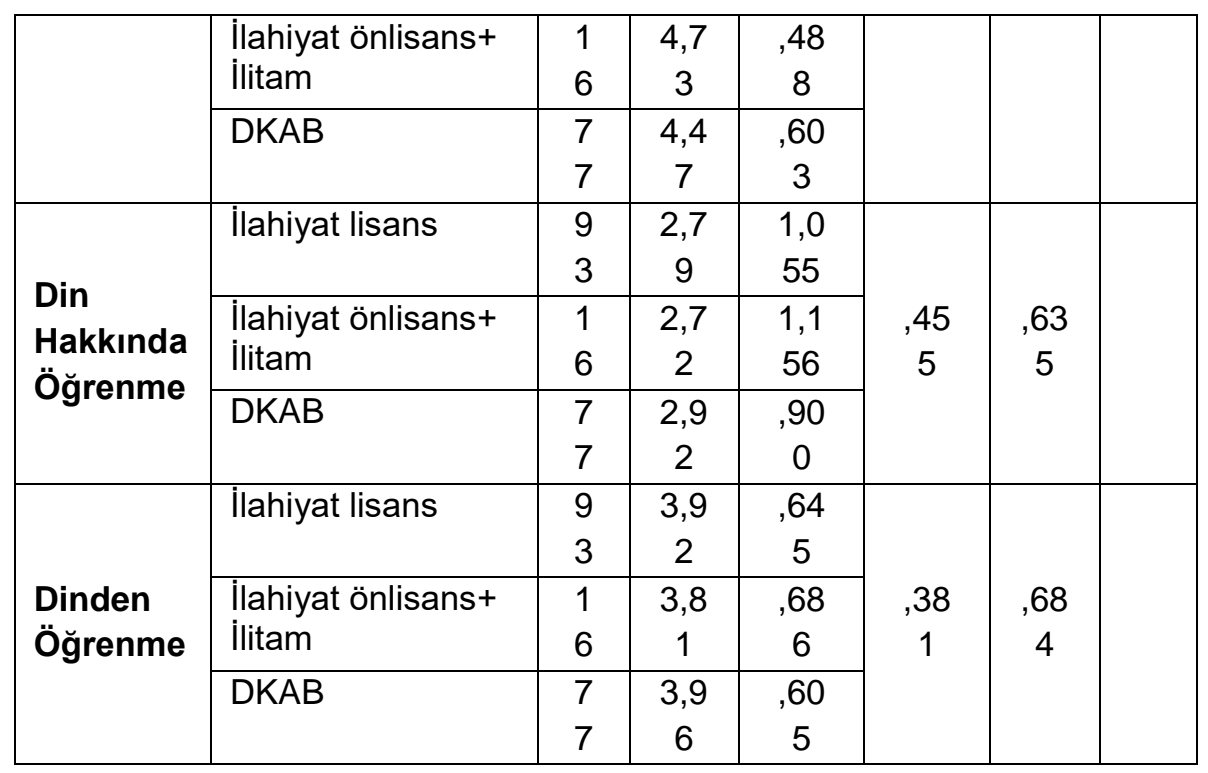

Tablo 7'de araştırmaya katılan DKAB öğretmenlerinin mezun oldukları lisans programı değişkenine göre DKAB derslerini din öğretimi modelleri çerçevesinde nasıl konumlandırdıklarına ilişkin tek yönlü varyans analizi (ANOVA) sonuçları yer almıştır. Yapılan analiz sonucunda öğretmenlerin mezun oldukları lisans programı değişkeninin dini öğrenme, din hakkında öğrenme ve dinden öğrenme yaklaşımlarının hiçbirinde anlamlı bir farkııı̆ga yol açmadığı görülmektedir. Bu durumda DKAB öğretmenliği bölümü mezunu öğretmenler, Illahiyat lisans ve ILITAM programlarından mezun olan öğretmenlere göre DKAB derslerini din hakkında ve dinden öğrenme modellerine daha fazla oranda uygun bulacakları şeklindeki araştırmanın dördüncü hipotezi doğrulanmamıştır.

\section{Tartışma, Sonuç ve Öneriler}

Günümüzün küreselleşen, seküler ve çoğulcu toplumlarında okullarda dinin yerinin ne olduğu ve kamu okullarında nasıl bir içerikle yer alması gerektiğine ilişkin tartışmalar devam etmektedir. Bu konuda gerek uluslararası gerekse de ulusal alanyazında giderek daha fazla çalışmanın yürütüldüğü görülmektedir. Her ülke kendi sosyo-kültürel, siyasal, tarihsel ve din-devlet ilişkisi geleneğine uygun olarak bu sorulara yanıtlar aramakta ve kendine uygun din eğitimi politika ve yaklaşımını belirlemektedir. Ancak öncesinde daha çok ulusal değişkenlere bağlı olarak belirlenen din eğitimi politikalarının, özellikle 2000'li yıllardan itibaren uluslararası boyutta da değerlendirilmeye tabi 
tutulduğu, uluslararası kuruluşlar ve sivil toplum örgütleri tarafından çeşitli çalışmalara konu edildiği görülmektedir. Bir anlamda okullarda din öğretimi konusunda nelerin kabul edilebilir nelerin kabul edilemez olduğu konusunda uluslararası seviyede daha önce hiç bulunmayan gelenekler oluşturulmaya başlanmıştır. Özellikle 11 Eylül 2001 sonrası süreçte din ile güvenlik arasında kurulmaya çalışılan ilişki, söz konusu ilginin temel saikini oluşturmaktadır. ${ }^{28}$ Özellikle devlet okullarda din derslerinin geleneksel bir mezhep veya dinin savunuculuğunu yapacak şekilde verilmesi eleştirilmeye başlanmıştır. Bunun yerine çoğulcu din eğitimi modellerinin daha uygun olacağı yönündeki görüşler başta akademisyenler arasında olmak üzere daha fazla ilgi görmüştür. ${ }^{29} \mathrm{Bu}$ gelişmeler herkese yönelik eğitim hizmeti sunan kamu okullarının programlarında yer alacak din öğretiminde dini öğrenme modelinden ziyade din hakkında öğrenme ve dinden öğrenme modellerinin daha kabul edilebilir olduğu sonucunu ortaya koymaktadır.

Din Kültürü ve Ahlak Bilgisi (DKAB) dersi ülkemizde anayasal olarak 1982 yılından itibaren ilk ve ortaöğretim kurumlarında zorunlu olarak okutulan dersler arasında yer almaktadır. Ancak önceleri Müslüman ve Müslüman olmayan ayrımı yapılmaksızın herkes için zorunlu olan bu derslerden, 1990 yılında alınan bir kararla Hıristiyanlık ve Musevilik dinlerine mensup olan öğrencilere muafiyet hakkı tanınmıştır. ${ }^{30}$ Buna karşılık toplumun farklı kesimlerinden özellikle laiklik ile din ve vicdan özgürlüğüne aykırı olduğu gerekçesiyle, dersin zorunluluğuna ciddi eleştiriler yöneltilmeye devam etmektedir. Bu derslerin zorunluluğu üzerine yürütülen tartışmalara, çocuklarını bu derslerden muaf tutmak isteyen Alevi velilerin başvuruları sonucunda 2007 ve 2014 yıllarında Avrupa İnsan Hakları Mahkemesi'nin vermiş olduğu kararlar da eklenmiştir. AlHM'in kararlarından; devlet okullarında zorunlu din derslerinin varlığını, tek başına Sözleşme'ye aykırı görmediği, ancak ölçüt olarak, söz konusu eğitimin "tarafsız, eleştirel ve çoğulcu" bir yaklaşımla verilmesini ve herhangi bir sistematik telkinde/fikir aşılamasında bulunulmamasını ileri sürdüğü anlaşılmaktadır. Her iki kararında da AiHM, bu kriterleri karşılama

\footnotetext{
${ }^{28} 11$ Eylül sonrası süreçte din eğitimi politika ve pedagoji anlayışlarında yaşanan değişimlere ilişkin bkz. Daniel Moulin, Religious Education in England After 9/11, Religious Education, 107:2, 2012: 158-173.

${ }^{29}$ Recep Kaymakcan, "Türkiye'de Din Eğitiminde Çoğulculuk ve Yapılandırmacılık: Yeni Ortaöğretim Din Kültürü ve Ahlak Bilgisi Programı Bağlamında Bir Değerlendirme”, Kuram ve Uygulamada Eğitim Bilimleri, 7:1, 2007: 177-210.

${ }^{30}$ MEB, Tebliğler Dergisi, 1990/2317:553.
} 
açısından DKAB derslerinin öğretim programlarını yetersiz bulmuştur. ${ }^{31}$ Din öğretimi modelleri açısından değerlendirildiğinde söz konusu mahkeme kararlarının da devlet okullarında zorunlu olarak yer alacak din öğretiminin dini öğrenme yaklaşımından ziyade din hakkında öğrenme ve dinden öğrenme modellerine uygun olmasını öngördüğü ifade edilebilir. Çünkü bu konuda getirmiş olduğu kriterler, daha çok bu iki modelin nitelikleriyle örtüşmektedir.

DKAB derslerine ilişkin yaşanan bu gelişmeler karşısında Milli Eğitim Bakanlığı dersin hukuki statüsünü değiştirmekten ziyade, öğretim programlarında 2010 ve 2018 yıllarında değişiklikler yaparak içeriğinin belirlenen kriterlere uygun hale getirilmesine ilişkin bir takım düzenlemeler yapmıştır. Söz konusu öğretim programlarında temele alınan yaklaşımlar hakkında yapılan açıklamalar, aynı zamanda bu derslerin din öğretimi modelleri arasındaki konumuna ilişkin de fikir vermektedir. 2018 yılında yayınlanarak yürürlüğe konulan ilk ve ortaöğretim DKAB öğretim programlarına bakıldığında temele alınan eğitimsel yaklaşıma ilişkin yapılandırmacı öğrenme modelini destekleyen çoklu zekâ, öğrenci merkezli öğrenme ve beceri temelli öğrenme gibi yaklaşımların dikkate alındığı ifade edilmektedir. Temele alınan dinbilimsel yaklaşım ise şu şekilde belirtilmektedir:

“Din Kültürü ve Ahlak Bilgisi Dersi Öğretim Programı, İslam dini ve diğer dinleri betimleyici yaklaşımla öğretime konu etmeyi amaçlamıştır. İslam dini Kur'an ve sünnetin ortaya koyduğu temel ilkeler çerçevesinde esas alınmıştır. İslam düşüncesinde ortaya çıkan yorumlar bilimsel bir metotla ve mezhepler üstü bir yaklaşımla ele alınmıştır. Yaşayan diğer dinler ise bilimsel bir metotla, dinler açılımlı ve olgusal bir yaklaşımla öğretime konu edilmiştir."

Bununla birlikte programın uygulanmasına ilişkin ilke ve açıklamalar başlığında ise

"Gerek farklı din ve inançların öğretiminde gerekse İslam düşüncesinde ortaya çıkan yorumların öğretiminde olgusal bir yaklaşım benimsenir; bu bağlamda dinler, inançlar ve İslam düşüncesinde yer alan yorumlar kendi metinleri, kaynakları ve kabulleri esas alınarak öğretime konu edilir.”

\footnotetext{
${ }^{31}$ Söz konusu Mahkeme kararları için bkz. Avrupa İnsan Hakları Mahkemesi, Hasan ve Eylem Zengin v. Türkiye, 9 E k i m 2007, 1448/04.; Avrupa İnsan Hakları Mahkemesi, Mansur Yalçın ve diğerleri Türkiye, 16 Eylül 2014, 21163/11.
} 
"Islam dininde yer alan ibadetlerin ögrretiminde (abdest, gusül, teyemmüm, namaz, vb.) mezheplerin farklı anlayış ve uygulamayla ilgili bilgiler, ihtiyaç duyulması hâlinde öğretmenler tarafından açıklanır.”

“Din, vicdan ve düşünce özgürlüğünü zedeleyici yaklaşım, tutum ve davranışlardan uzak durulur. Bu bağlamda öğrenciler dinî duygu ve düşüncelerini açıklamaya, bilgi ve kültür sahibi oldukları dinî pratikleri yerine getirmeye zorlanmaz."

şeklindeki maddelerle DKAB öğretmenlerinin programın uygulanması sürecinde nasıl bir yaklaşım benimsemeleri gerektiğine ilişkin açıklamalara yer vermektedir. ${ }^{32}$

Programda yer alan bu açıklamalarda DKAB dersinde İslam da dâhil herhangi bir dinin benimsetilmesinin amaçlanmadığı ve hem diğer dinlerin hem de İslam içerisindeki farklılıkların betimleyici tarzda, olgusal bir yaklaşımla öğretime konu edildiği ve öğretmenlerden de uygulama sürecinde böyle bir yaklaşım benimsemelerinin istendiği anlaşılmaktadır. Bu şekilde öğretim programından yer aldığı şekliyle bu derslerin din öğretimi modelleri açısından din hakkında öğrenme modeline uygun hale getirilmeye çalışıldığını söylemek mümkündür. Nitekim dini gelenekler açısından betimsel ve olgusal bir dilin kullanılması bilimsel yaklaşımın öncelenmesi daha çok din hakkında öğrenme modelinin nitelikleriyle örtüşmektedir. Kızılabdullah ve Yürük ise yaptıkları çalışmada, yine bu derslerin 2006 yılındaki öğretim programındaki eğitimsel ve dinbilimsel yaklaşımdan hareketle, bu derslerin diğer iki modelin bazı özelliklerini yansıtsa da özellikle genel eğitimin bir birimi olarak kabul edilmesi, bireysel, sosyal, kültürel vb. açıdan öğrenci gelişimine katkıda bulunmayı öngörmesi ve sorgulayıcı, eleştirici, bilgiyi üreten vb. özelliklere sahip öğrenciler yetiştirmeyi hedeflemesinden dolayı dinden öğrenme yaklaşımına daha yakın olduğunu ifade etmektedir. ${ }^{33}$ Özellikle programların eğitimsel yaklaşım olarak temele aldığı yapılandırmacı, öğrenci merkezli yaklaşımlar göz önünde bulundurulduğunda bu çıkarıma ulaşmak mümkünse de dinbilimsel yaklaşım itibariyle din hakkında öğrenme yaklaşımını daha fazla yansıttığını söylemek mümkündür.

Bu çerçevede öğretim programlarında daha çok din hakkında öğrenme modelini yansıtmaya çalışan DKAB derslerinin uygulayıcıları olan öğretmenleri

\footnotetext{
${ }^{32}$ MEB, Ortaöğretim Din Kültürü ve Ahlak Bilgisi Öğretim Programı, (Ankara: MEB, 2018), 8.

${ }^{33}$ Kızılabdullah ve Yürük, "Din Eğitimi Modelleri Çerçevesinde Türkiye'deki Din Eğitimi Üzerine Genel Bir Değerlendirme", 129.
} 
tarafından nasıl konumlandırdıklarının tespitini amaçlayan bu çalışmada elde edilen sonuçlar ise şu şekildedir:

Araştırma sonucunda elde edilen verilere göre araştırmaya katılan DKAB öğretmenlerinin büyük bir çoğunluğu yürüttükleri DKAB derslerini dini öğrenme yaklaşımına uygun bir ders olarak konumlandırmaktadır $(X=4,54)$. Yine öğretmenlerin önemli bir kısmı bu dersleri dinden öğrenme yaklaşımına uygun bir ders olarak algılarken $(X=3,93)$, öğretmenlerin en az katılım gösterdikleri yaklaşım ise din hakkında öğrenme modeli olduğu tespit edilmiştir $(X=2,84)$.

Araştırmaya katılan öğretmenlerin DKAB derslerini din öğretimi modelleri çerçevesinde nasıl konumlandırmalarına ilişkin puan ortalamalarına bazı değişkenler açısından bakıldığında, cinsiyet değişkeninin dini öğrenme ve dinden öğrenme yaklaşımlarında anlamlı bir farklılık oluşturmadığı, buna karşılık din hakkında öğrenme yaklaşımında istatistiksel olarak anlamlı bir farklılığa yol açtığı sonucuna ulaşılmıştır. Buna göre kadın DKAB öğretmenleri, erkek meslektaşlarına göre DKAB derslerini daha fazla oranda din hakkında öğrenme yaklaşımına uygun bir ders olarak algılamaktadır.

Araştırmaya katılan öğretmenlerin DKAB derslerini din öğretimi modelleri çerçevesinde nasıl konumlandırmalarına ilişkin puan ortalamalarına öğrenim durumu değişkeni açısından bakıldığında, dini öğrenme ve din hakkında öğrenme yaklaşımlarında anlamlı bir farklılığın ortaya çıkmadığı, buna karşılık dinden öğrenme yaklaşımında ise lisansüstü mezunu DKAB öğretmenlerinin, lisans derecesine sahip meslektaşlarına göre DKAB derslerini daha fazla oranda dinden öğrenme yaklaşımına uygun bir ders olarak algıladıkları sonucuna ulaşılmıştır. Bu durumun ortaya çıkmasında lisansüstü derecesine sahip öğretmenlerin bu öğrenimleri esnasında aldıkları derslerin ve edindikleri bilgilerin onların bu konudaki bakış açılarına etki ettiği söylenebilir.

Yaş değişkeni açısından öğretmenlerin DKAB derslerini konumlandırmalarına bakıldığında, sadece dini öğrenme yaklaşımında istatistiksel olarak anlamlı bir farklılığın oluştuğu ve 51 ve üzeri yaşa sahip DKAB öğretmenleri diğer yaş aralıklarındaki öğretmenlere göre DKAB derslerini daha fazla oranda dini öğrenme yaklaşımına uygun bir ders olarak algıladıkları tespit edilmiştir. Özellikle 51 ve üzeri yaşa sahip öğretmenlerin öğrenciliklerinden itibaren dini öğrenme modeline uygun bir din öğretimiyle meslektaşlarına göre daha uzun süre maruz kalmış olmaları, onların bu şekilde bir algıya sahip olmalarında etkili olduğu ileri sürülebilir. Araştırma sonucunda öğretmenlerin mezun oldukları lisans programı değişkeninin ise DKAB 
derslerini konumlandırmaları açısından herhangi bir modelde anlamlı bir farklılığa yol açmadığı saptanmıştır.

Sonuç olarak araştırmada elde edilen verilere göre DKAB dersi öğretim programlarının ortaya koyduğu din öğretimi yaklaşımı ile uygulayıcıları olan öğretmenlerin bu dersleri konumlandırdığı yaklaşım birbiriyle örtüşmemektedir. Yani öğretim programı bu dersleri din hakkında öğrenme modeline yaklaştırmaya çalışırken, öğretmenleri bu modele en az düzeyde katılım göstermektedir. Öğretmenlerin dinden öğrenme yaklaşımına din hakkında öğrenme yaklaşımına göre daha yüksek katılım göstermesi ise muhtemelen derslerin öğretim programlarındaki öğrenci merkezlilik vurgusundan kaynaklanmaktadır. Çıkan bu sonuç DKAB öğretmenlerinin hizmet öncesi yetiştirildikleri programların ve yetiştirilme sistemlerinin bu bağlamda yeniden gözden geçirilmelerini ve mevcut öğretmenlerin ise hizmetiçi eğitimlerinde DKAB derslerinin statüsü ve amaçlarına ilişkin daha fazla bilgilendirilmelerini gerekli kılmaktadır. Yine söz konusu değişkenler açısından ortaya çıkan farklılıkların altındaki nedenlerin detaylı olarak incelendiği nitel ve nitel araştırmalara intiyaç vardır.

Öğretmenlerin DKAB derslerini nasıl algıladıklarına ilişkin yeterince çalışma olmaması, Malatya ili merkez ilçelerinde görev yapan öğretmenler üzerine yapılan bu araştırmada elde edilen sonuçları genellemeyi güçleştirmektedir. Bu nedenle konu üzerine farklı örneklemlerle gerçekleştirilecek daha fazla nicel ve nitel araştırmanın yürütülmesi, bu derslerin öğretim sürecindeki öğretmen tutum ve davranışlarından kaynaklanan sorunların tespiti ve giderilmesine katkı sağlayıcı olacaktır. Bu çaba aynı zamanda teorik olarak bu derslerin öğretim programlarında belirlenen amaçlarına uygun bir şekilde pratikte de yürütülmesine imkân sunacak, bu derslerle ortaokul ve lise programlarında seçmeli olarak yer alan din eğitimi derslerinin doğru konumlandırılmalarına hizmet edecektir.

\section{Kaynakça}

Avrupa İnsan Hakları Mahkemesi. Hasan ve Eylem Zengin v. Türkiye. 9 E k i m 2007. 1448/04.

Avrupa İnsan Hakları Mahkemesi. Mansur Yalçın ve diğerleri Türkiye. 16 Eylül 2014. 21163/11.

Bazarkulov, Seyfullah. Değer Öğretimi ve Dinden Öğrenme. Doktora Tezi. Ankara Üniversitesi, 2008. 
COUNCIL of Europe, Religious Diversitiy and Intercultural Education: $A$ Reference Book For Schools

Doğan, Recai. "Avrupa Birliği Sürecinde Dini Kurumlar ve Din Eğitimi: Almanya Modeli”. Avrupa Birliği Sürecinde Dini Kurumlar ve Din Eğitimi Uluslararası Sempozyum, (İstanbul 17-19 Kasım 2006), İstanbul, Dem Yayınları, 2007: 255-299.

Ferrari, Alessandro. "Avrupa Birliği Sürecinde Dini Kurumlar ve Din Eğitimi: İtalya Modeli”. Avrupa Birliği Sürecinde Dini Kurumlar ve Din Eğitimi Uluslararası Sempozyum, (İstanbul 17-19 Kasım 2006), İstanbul, Dem Yayınları, 2007: 461-480.

Grimmit, Michael. "Contemporary Pedagogies of Religious Education: What are they?", Pedagogies of Religious Education, UK, McCrimmons, 2000: 2452.

Hull, John M. "Demokratik Çoğulcu Toplumlarda Din Eğitimi Üzerine Genel Değerlendirme", Din Öğretiminde Yeni Yöntem Arayışları, Uluslar arası Sempozyum Bildiri ve Tartışmalar (İstanbul, 28-30 Mart 2001). Ankara, MEB Yayınları, 2003. 33-51.

Işıkdoğan, Davut ve Korukcu, Adem. "Ilköğretim Din Kültürü ve Ahlak Bilgisi Dersi Öğretim Programı ve Öğretmenlerin Programa Yönelik Görüşleri”. Dini Araştırmalar 11/32 (Eylül-Aralık 2008): 237-258.

Jackson, Robert. "Avrupa'da Kurumlar ve Din Öğretimi-Öğreniminin Kamusal alandaki Genel Eğitime Katkısı". Avrupa Birliği Sürecinde Dini Kurumlar ve Din Eğitimi Uluslararası Sempozyum. (İstanbul 17-19 Kasım 2006). İstanbul, Dem Yayınları, 2007:119-158.

Jackson, Robert. "Devlet Okullarında Din Eğitimi ve Değerler Eğitimine Yorumcu Yaklaşımın Katkısı", Değerler ve Eğitimi. İstanbul, 26-28-Kasım 2004. ed. Recep Kaymakcan vd. 467-488. İstanbul: Dem Yayınları, 2007.

Jackson, Robert. Rethinking Religious Education and Plurality. London and Newyork: Routledge Falmer, 2004.

Karasar, Niyazi. Bilimsel Araştırma Yöntemi. Ankara: Nobel Yayınları, 1999.

Kaymakcan, Recep. Gençlerin Dine Bakışı: Karşılaştırmalı Türkiye ve Avrupa Araştırması. İstanbul: Dem Yayınları, 2007.

Kaymakcan, Recep. "Türkiye'de Din Eğitiminde Çoğulculuk ve Yapılandırmacılık: Yeni Ortaöğretim Din Kültürü ve Ahlak Bilgisi 
Programı Bağlamında Bir Değerlendirme". Kuram ve Uygulamada Eğitim Bilimleri. 7:1, 2007:177-210.

Kaymakcan, Recep. Öğretmenlerine Göre Din Kültürü ve Ahlak Bilgisi Dersleri Yeni Eğilimler: Çoğulculuk ve Yapılandırmacılık. İstanbul: Dem Yayınları, 2009.

Kızılabdullah, Yıldız "Dini Öğrenme Modelinin” Çok Dinli /Çokkültürlü Toplumlardaki Tezahürleri. Pegem Eğitim ve Öğretim Dergisi, 5(5): 721 732.

Kızılabdullah, Yıldız ve Yürük, Tuğrul. "Din Eğitimi Modelleri Çerçevesinde Türkiye'deki Din Eğitimi Üzerine Genel Bir Değerlendirme”. Dini Araştırmalar, 11/32, (Eylül-Aralık 2008): 107-129.

Milli Eğitim Bakanlığı, Tebliğler Dergisi, 1990/2317.

Milli Eğitim Bakanlığı. Ortaöğretim Din Kültürü ve Ahlak Bilgisi Öğretim Programı. Ankara: MEB, 2018.

Moulin, Daniel. "Religious Education in England After 9/11". Religious Education. 107:2, 2012: 158-173.

Okumuşlar, Muhittin. "Çokkültürlü Toplumlarda Din Hakkında ve Dinden Öğrenme Modeli”. Marife, 7/2, (Güz 2007): 251-264.

OSCE, Toledo Guiding Principles on Teaching About Religions and Beliefs in Public Schools, Warsaw, 2007. OSCE (2007) http://www.osce.org/odihr/29154?download=true

Tabachnick, Barbara. G. and Fidell, Linda S. Using Multivariate Statistics (sixth ed.). Boston: Pearson, 2013.

Tavşancıl, Ezel. Tutumların Ölçülmesi ve SPSS ile Veri Analizi. Ankara: Nobel Yayıncılık, 2014.

Tosun, Cemal. Din Eğitimi Bilimine Giriş. Ankara, Pegem A Yayıncılık, 2001.

Yürük, Tuğrul. "Öğretmenlere Göre İlköğretim DKAB Dersi Öğretim Programının Eğitim Anlayışı (Adana Örneği), Dini Araştırmalar, 17/45, (Temmuz-Aralık 2014): 171-207.

Yürük, Tuğrul. "Öğretmenlerin İlköğretim Din Kültürü ve Ahlak Bilgisi Dersi Öğretim Programının Din Anlayışına Yönelik Düşünceleri (Adana Örneği), Dini Araştırmalar, 18/46, (Ocak-Haziran 2015): 148- 170. 
Öğretmenlerine Göre Din Kültürü ve Ahlak Bilgisi Dersinin Din Öğretimi Modelleri Çerçevesinde Konumlandırılması | 743

Zengin, Mahmut. "Yeni Illköğretim DKAB Öğretim Programının Uygulamadaki Etkililiğinin Değerlendirilmesi. Sakarya Üniversitesi Ilahiyat Fakültesi Dergisi, 12/22, 2010:121-160. 


\section{Position of Religious Culture and Ethics Knowledge Course within the Framework of Religious Education Models According to Religious Course Teachers}

Citation / @- Aşlamacı, İ. (2018). Position of Religious Culture and Ethics Knowledge Course within the Framework of Religious Education Models According to Religious Course Teachers, Cukurova University Journal of Faculty of Divinity, 18 (2), 718-744.

Abstract- In this study it is aimed to examine how religious course teachers position religious culture and ethics knowledge course in the context of religious education models. The study was designed by descriptive survey and comparative associative models. The sample of the study composed of 187 religious teachers working in the 2017-2018 school year, in the central districts of Malatya, Turkey. The data were collected using "Teacher Religious Culture and Ethics Knowledge Course Perception Scale" originally developed by the researcher. As a result of the research, it was determined that the majority of the teachers appropriately position the religious culture and ethics knowledge course to the learning religion approach.

Keywords: Religious culture and ethics knowledge course, religious course teacher, models of religious education, learning religion, learning about religion learning from religion. 